\title{
INTEGRATION OF LOCAL CULTURE IN ARABIC LESSON MATERIALS IN MADRASAH TSANAWIYAH DARUL HIKMAH SINJAI
}

\author{
Abu Darda ${ }^{1}$ \\ Muzakkir $^{2}$ \\ Haniah $^{3}$ \\ Alauddin State Islamic University Makassar, Indonesia ${ }^{1,2,3}$ \\ abudarda0792@gmail.com¹, muzakkir.ftkuin@gmail.com², \\ haniah@uin-alauddin.ac.id ${ }^{3}$
}

\begin{abstract}
This study aims to explore procedures or steps for the development of Arabic subject matter through the integration of local culture in Sinjai Regency into Arabic subject matter at Madrasah Tsanawiyah Darul Hikmah Sinjai and test the feasibility of Arabic language subject matter that is integrated with the local culture of Sinjai district. at Madrasah Tsanawiyah Darul Hikmah Sinjai. This research is a type of research and development or Research and Development (R\&D) using four stages of research, namely, the data collection stage, the planning stage, the product development stage, and the product validation and testing stage. The instruments used were questionnaires, interviews and, observations. The results showed that the process of developing Arabic subject matter by integrating local Sinjai culture was carried out in six steps as follows, conducting field studies and literature studies on Sinjai local culture, determining and compiling materials, integrating local culture into Arabic subject matter for class VII Madrasah Tsanawiyah Arabic. into Arabic, material systematization, material validation includes internal validation and external validation. the internal test percentage reached $64.02 \%$. And the external test results using the Wilcoxon type nonparametric statistical analysis is .003 which means less than $0.05(0030.05)$, these two test results indicate that the product is suitable for use.
\end{abstract}

Keywords: Integration of Local Culture; Arabic Language Study Materials

\section{INTRODUCTION}

Learning Arabic as a foreign language is different from learning Arabic as a mother tongue. If you learn Arabic as your mother tongue, then the need to learn Arabic is clear, that is, to meet your daily needs, because only with that language all your needs can be met. However, if learning Arabic as a foreign language, then it is not just for fulfilling daily needs, but clearly as a skill outside the habits of everyday life. Thus, motivation, interest and other efforts to learn Arabic as a foreign language must be higher than learning materials related to just meeting daily needs, or at least the same as learning other materials such as learning Indonesian, mathematics. , history, and others.

In the context of education in Indonesia, every language lesson other than Indonesian and regional languages that are studied or become one of the subjects in certain educational units is called a second language or foreign language, so that in the learning process there will be many motives in it. And because the foreign language is 
something new, at least the lesson must have a strong enough appeal to attract students' interest in learning. One of them is in terms of the material in the lesson. One of the many foreign languages that is required to be studied in schools, especially in Madrasas, is Arabic.

Basically, learning material is an option that is expected to suit the "tastes" of students for consumption or at least be important information for self-development. Therefore, there is a strong tendency that materials that suit their needs will be more in demand and the results achieved in mastering these materials are higher than materials that are less desirable because they are not suitable for their needs. Thus, the analytical question arises, what exactly is needed by students in Arabic, how do these needs arise and how are the solutions to meet those needs?

In the sociological perspective of education, a person's character, behavior, interests, motivation, mindset, and needs cannot be separated from the social environment that surrounds him, as well as educational needs. Students tend to be more interested in things that have to do with their daily lives. Therefore, a good education or learning process must be closely related to the social context of students. Social context can be used as material, source, media and learning environment. However, the use of the social context in the learning process really depends on the ability of an educator to construct it appropriately. ${ }^{1}$ Based on the decree of the Minister of Religion of the Republic of Indonesia Number 165 of 2014 concerning the 2013 curriculum for Religion and Arabic subjects, the student learning load for Arabic subjects for each level is three (3) hours per week and the content is developed by the center. In this decision, it is stated that the Arabic Language Subject is a subject that is directed to encourage, guide, develop, and foster abilities and foster positive attitudes towards Arabic both receptive and productive. Receptive ability is the ability to understand other people's speech and understand reading. Productive ability is the ability to use language as a means of communication both orally and in writing. The ability to speak Arabic as well as a positive attitude towards Arabic is very important in helping students understand the sources of Islamic teachings, namely the Al-Qur'an and Hadith, as well as Arabic books concerning Islam for students. ${ }^{2}$ It is further stated that the objectives of Arabic lessons are as follows: first, to develop the ability to communicate in Arabic, both spoken and written, which includes four language skills, namely listening (istima '), speaking (kalam), reading (qira'ah). ), and write (kitabah). Second, to raise awareness about the importance of Arabic as a foreign language to be the main learning tool, especially in studying the sources of Islamic teachings. Third, develop an understanding of the interrelationship between language and culture and broaden cultural horizons. Thus, students are expected to have cross-cultural insight and involve themselves in cultural diversity. ${ }^{3}$

The scope of space in question, for Madrasah Tsanawiyah, includes themes in the form of oral and written discourses in the form of simple explanations or dialogues about self-identity, madrasah life, family life, home, hobbies, professions, religious

${ }^{1}$ M Ag Munir, Perencanaan Sistem Pengajaran Bahasa Arab; Teori Dan Praktik (Kencana Prenada Media Group, 2017).

2 Mulabbiyah Mulabbiyah, "Implementasi Kurikulum 2013 Pada Mata Pelajaran Pendidikan Agama Islam Berdasarkan KMA Nomor 165 Tahun 2014 Di Madrasah,” Jurnal Tatsqif 16, no. 2 (2018): $108-25$.

${ }^{3}$ Mulabbiyah. 
activities, and the environment. ${ }^{4}$ Meanwhile, Arabic subjects at Madrasah Aliyah consist of materials in the form of oral and written discourse in the form of exposure or dialogue about introductions, family life, hobbies, work, youth, health, public facilities, tourism, Islamic stories, Islamic insight, Islamic holidays and Islamic figures to train the four aspects of language skills, namely listening, speaking, reading, and writing.

Apart from the material studied in the madrasas, however, in reality, learning a second language or also known as a foreign language such as Arabic makes it difficult for learners or learners to understand the language. The difficulties in question are: Difficulty reading. The ability of most students in terms of reciting the Koran or reading the Qur'an is still lacking so that they have difficulty learning Arabic because they are unable to read every dialogue or word in Arabic subject matter. Difficulty communicating. To carry out good communication, of course a good environment is needed, the environment in question is certainly the environment to help the communication run. Likewise, communicating using Arabic requires a conducive environment so that Arabic becomes the language used in communication. However, almost all Madrasah schools in Sinjai Regency and especially in Madrasah Tsanawiyah Darul Hikmah, the environment is not conducive to communicating in Arabic, this is due to several things, including local languages that are very dominant in the school environment, there is very little interlocutor to apply speaking skills. with Arabic, and Arabic learning is only centered in the classroom so that students easily feel bored. Difficulty understanding. The material which is the content in foreign language lessons, in this case Arabic is something that is not inherent and unfamiliar in the lives of students so that students feel distant and difficult to understand the subject matter because the discussion is something that does not exist in their daily life. Even though the subject matter has been adapted to the Indonesian context, it cannot be denied that the conditions of each region in Indonesia are very diverse, not only community activities but also language, culture and community paradigm in each region of course and must be different. Therefore, an integration process is needed. local culture into Arabic language subject matter. So, students continue to learn Arabic but the content of the subject matter is about the culture or daily lives of the students themselves. Apart from the three things mentioned above, there are other challenges for Arabic language teachers, namely:

1. Students' assumptions about Arabic. Most students consider that Arabic does not reflect or indicate modernity or in other words that Arabic is outdated, ancient, old-fashioned and very traditional.

2. The material taught in Arabic is not relevant to the conditions of the local community so that the material has no appeal and will be easily forgotten by students.

Departing from several points about the difficulty in understanding and learning a language which in this case is Arabic, in fact it must be seen as an integral part that language is not something that stands alone, but something that is integrated with other things such as social, psychological, economic and education of course. In terms of psychology, language development is influenced by the environment, because language is basically the result of learning from the environment. Children learn language like any other learning, "imitate" and "repeat" the results that have been obtained is a way of

\footnotetext{
${ }^{4}$ Mulabbiyah.
} 
learning early languages. Language development is the increase in the ability to master communication tools, both oral, written, and using signs and signs. ${ }^{5}$

Therefore, it is clear that language skills are very relevant or have a close relationship with the environment in which a person lives. The environment in which children grow and develop contributes significantly to language. The development of language in an urban environment will be different from that in a rural environment. Likewise the development of language in coastal areas, mountains, and remote areas and in other social groups. ${ }^{6}$ In addition, what must be underlined is that the language development of students is not only seen or measured from the value obtained from the test results but the most objective measure is seen from their ability to communicate using the language studied in this case, namely Arabic.

Therefore, the attractiveness of a subject matter is very important for developing students' language skills. When associated with the sociological context, matters related to the environment of students will make them inclined towards these things, because if these customs or cultures can be integrated into subject matter, especially Arabic subject matter, it will be very memorable and attached to students because the material provided is considered something familiar because they experience directly, in this case students are able to imagine themselves into a story or situation that they experience every day but this is stated in Arabic so that interest arises. learners to Arabic.

1. From the above explanations, several things can be formulated as follows.

2. That, the subject matter must be in accordance with the "tastes" or needs of students.

3. That in a sociological perspective, education or a good learning process must be closely related to the social context of students. Social context can be used as subject matter.

4. Based on the Decree of the Minister of Religion number 165 of 2013 concerning the 2013 curriculum for Islamic religious education and Arabic in Madrasas, that one of the coverage of Arabic subject matter for Madrasah Tsanawiyah is about the environment.

5. That psychologically, language development is influenced by the environment, because language is basically the result of learning from the environment. Because language and environment are very closely related.

Departing from some of these formulations, the socio-cultural conditions that exist in the students 'environment will be something that has the potential to attract and encourage interest and may even improve the quality of students' language skills with the basic assumption that what they are learning is their socio-cultural life. themselves or something that is very close to their lives, so that students will more easily abstract the existing material substance because it is experienced directly by students.

Although in fact this cultural integration can be carried out by Arabic language teachers at each madrasa, this depends on the ability and competence of each teacher and the fact is that most Arabic teachers at Madrasas are very much concerned with textbooks in madrasas so that it will be difficult. If the integration process is left to each teacher but it will be different and will make it easier for the teachers if the books they

\footnotetext{
${ }^{5}$ Hartono\& Sunarto and Agung Hartono, Perkembangan Peserta Didik, Jakarta: Rineka Cipta,

${ }^{6}$ Sunarto and Hartono.
} 2018. 
use have been integrated with local culture according to the regional conditions of each madrasa, at least each Arabic teacher has a basis and guidelines on how to integrate local culture into the Arabic language subject matter. This is expected to make Arabic learning more applicable and active, not just a subject in school and tested in the exam process. This can be seen in the output of Arabic language learning so far, especially in Sinjai district, that the majority of alumni from madrasas, either Madrasah Tsanawiyah or Madrasah 'Aliyah, are not able to speak Arabic, even the majority of them are unable to write Arabic properly and correctly. This is of course a concern for most groups, especially for researchers personally, that learning Arabic so far has not been able to achieve the objectives of learning Arabic itself. The objective in question is based on the Decree of the Minister of Religion of the Republic of Indonesia number 165 of 2014. This study aims to explore the procedures or steps for developing Arabic learning material through the integration of local culture in Sinjai district into Arabic language subject matter at Madrasah Tsanawiyah Darul Hikmah Sinjai. Testing the feasibility of Arabic language subject matter that is integrated with the local culture of the Sinjai district at Madrasah Tsanawiyah Darul Hikmah Sinjai as a new product from the research and development process of subject matter.

\section{RESEARCH METHODS}

a. Types of research

This research is a type of research and development or Research and Development (R\&D). According to Sugiyono ${ }^{7}$ research and development is a research method used to produce certain products and test the effectiveness of these products. Nana Syaodih Sukmadinata ${ }^{8}$ defines research and development as a process or steps to develop a new product or improve an existing product, which can be justified. So, development research is a method for producing certain products or improving existing products and testing the effectiveness of these products. In this research, researchers seek to conduct research and development in order to produce new products, improve products, and test the effectiveness of these products.

\section{b. Research Procedure}

In order to develop a product, the development procedure used is Borg and Gall's theory. The development stages are as follows: (1). Research and data collection (research and information collecting) which includes measurement of needs, study of literature, research on a small scale, and considerations in terms of value. (2). Planning (planning), namely compiling a research plan, including the capabilities needed in conducting research, formulation of objectives to be achieved with the research, design or research steps, and possibly in a limited scope. (3). Development of a product draft (develop a preliminary form of product). Development of learning materials, learning processes, and evaluation instruments. (4). Preliminary field testing (preliminary field testing). (5). Revision of test results (main product revision). (6). Field testing (main

\footnotetext{
${ }^{7}$ Prof Sugiyono, Metode Penelitian Kuantitatif, Kualitatif Dan R\&D, Alpabeta, Bandung, 2017.

${ }^{8}$ Nana Syaodih Sukmadinata, Metode Penelitian Pendidikan, Bandung: Remaja Rosda Karya, 2013.
} 
field testing). (7). Improvement of field test results (operational product revision). (8). Field implementation test (operational field testing). (9). Final product revision. (10). Dissemination and implementation (dissemination and implementation).

In thesis and dissertation research, Borg \& Gall suggested as expressed by Emzir ${ }^{9}$ to limit research on a small scale, including the possibility of limiting the steps of research. After paying attention to the procedures and steps in research and development and as suggested by Borg \& Gall, based on this, the application of developmental steps in this study was tailored to the needs and abilities of the researcher. Given the limited time and funds owned by researchers, these steps are simplified into four development steps. The development steps taken by the researcher are illustrated in the following chart:

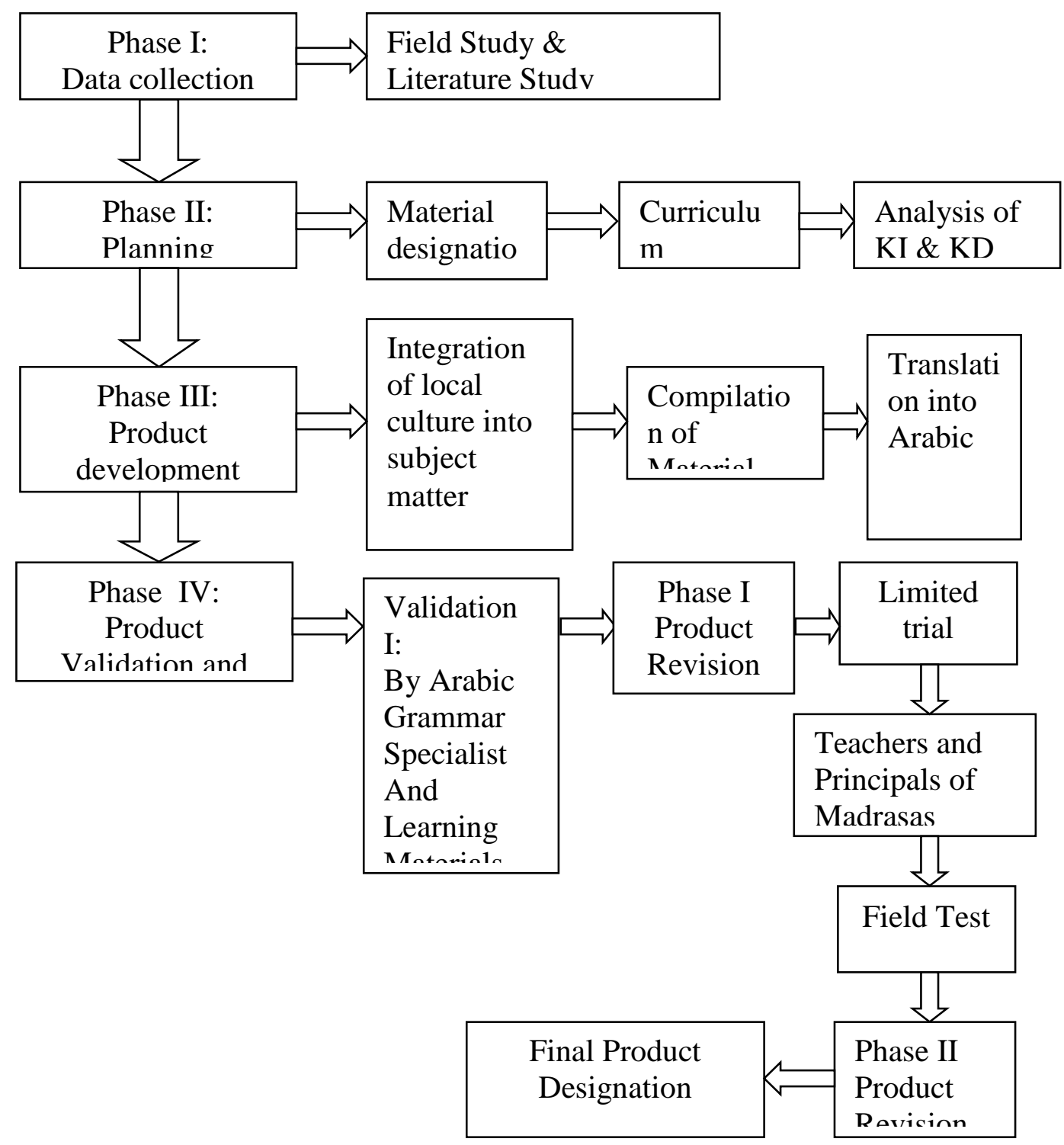

Figure 1. Research and Development Procedure

${ }^{9}$ Metodologi Emzir, Metodologi Penelitian Pendidikan: Kuantitatif Dan Kualitatif, Jakarta: Raja Grafindo Persada, 2015. 


\section{c. Population and Sample}

The population or data sources in this study have differences based on the stages in the study. For the field study stage, the population or data source was 3 humanists, community leaders in Sinjai Regency. For the internal validation stage by experts, it is clear that the data source or population is experts. The experts here are Arabic grammar experts and experts on Arabic learning materials, amounting to 4 people. For the external validation stage by the teacher, the Head of Madrasah Tsanawiyah amounted to 7 people and the Grade VII Madrasah Tsanawiyah Darul Hikmah Sinjai students were 22 students.

\section{d. Product Trial}

Before being tested, the product development of Arabic subject matter integrated with the local culture of Sinjai Regency was validated first by learning material experts and Arabic grammar experts, then revision of stage I. The validated products were then tested on Arabic subject teachers and the head of Madrasah Tsanawiyah Darul Hikmah Sinjai, then field tests were carried out on the seventh grade students of Madrasah Tsanawiyah Darul Hikmah Sinjai. The results of the trial were limited to teachers and principals of madrasah and field trials to students, then the stage II revision was carried out.

The subject of the product trial for the development of Arabic learning materials integrated with the local culture of Sinjai Regency was the Madrasah Tsanawiyah Darul Hikmah Sinjai Arabic teacher, a grade VII student of Madrasah Tsanawiyah Darul Hikmah Sinjai. The selection of limited trial subjects was done randomly and for a wider trial it was carried out for the entire population who were also the trial subjects.

\section{e. Type of Data}

In accordance with the objectives of this research and development, the data collected consisted of two kinds, namely; (1). Data regarding the process of developing Arabic teaching materials at Madrasah Tsanawiyah Darul Hikmah Sinjai which is integrated with the local culture of Sinjai Regency according to predetermined procedures. This data comes from the assessment and input of learning material experts, Arabic grammar experts, teachers and madrasah principals. (2). Data about the results of product trials for the development of teaching materials in Arabic subjects at Madrasah Tsanawiyah Darul Hikmah Sinjai which are integrated with local culture of Sinjai Regency based on trials of use by Madrasah Tsanawiyah Darul Hikmah Sinjai students.

\section{f. Data Collection Instruments}

This study uses three forms of data collection instruments, it is hoped that the data obtained is more accurate and valid. And instruments in the form of: (1). Questionnaire; The questionnaire made was a questionnaire regarding the feasibility of teaching materials in Arabic for Madrasah Tsanawiyah Darul Hikmah Sinjai. This questionnaire is prepared based on the criteria for developing good teaching materials. This questionnaire was made for learning material experts, Arabic grammar experts, teachers, Madrasah principals and students with different questionnaires according to their respective functions and interests. (2). Interview; In this study, researchers 
conducted interviews with data sources about local culture in Sinjai Regency, in this case, cultural figures and community leaders in East Sinjai. Whereas for matters related to teaching materials, initial information is needed about teaching materials or subject matter relevant to students at Mdarasah Tsanawiyah Darul Hikmah Sinjai, the sources are teachers, Madrasah heads and students. (3). Observation; The selection of this observation will be used during the product testing process or external validation in the classroom during the learning process using research products. The observation model that will be used is systematic observation, which has an observation sheet as a guide or reference in the observation process, making it easier to provide an assessment or measurement of the object being observed. g. Data analysis technique Testing the data in this study using statistical data analysis with the prerequisite for analysis by conducting data normality tests. The normality test is used to determine whether the data in this study are normally distributed. The normality test used the KolmogorovSmirnov test using the IBM SPSS 20. for windows computer program. After the normality test was carried out, it was continued with a nonparametric statistical analysis of the Wilcoxon type. Nonparametric statistical analysis was performed because the data were not normally distributed.

\section{III.RESEARCH RESULTS AND DISCUSSION}

\section{a. Brief overview of Sinjai Regency}

Tellu Limpoe is the name or designation for the area currently known as Sinjai. Tellu Limpoe is the name for the land of the three kingdoms, namely Tondong, Bulobulo and Lamatti. Regarding the origin of the name or designation Sinjai, there are several versions including: There is an assumption that the name Sinjai comes from a person's name, To Saja. What is meant by To Saja is the first person who succeeded in creating unity between community groups held by Timpae Tana, a descendant of Manurung ri Ujung Lohe. The Gowa version states that, when Somabaya (king of Gowa $\mathrm{X}$, I Manriogau Daeng Bonto Karaeng Lakiung Tunipallangga Ulaweng) was on his way back to Gowa from his war in the Bone kingdom in the middle of the XIV century at night in the waters of the Gulf of Bone. Your Majesty turned to the land on the coast of Mangara'bombang and asked "what rate? Kerejai balla'na ri maccini sombala? (What land is there on the mainland? Where are more houses than Maccini Sombala?

However, when tracing the relationship between the kingdoms that existed in the Sinjai area in the past, it is clear that the kingdoms were tightly knit by kinship rope which in Bugis language is called "sijai" which means one stitch and Sinjai is the same stitch. This was made clear by the idea of Lamatti $X$ to further strengthen the unity of the Bulo-bulo and Lamatti kingdoms with the phrase "pasijai singkerruanna lamtti Bulobulo" which means to unite Lamatti Bulo-bulo's beliefs so that after his death he was held with Puatta Matinroe Risijai na. ${ }^{10}$ based on this, the name Sinjai was born. In the Sinjai area, there were several kingdoms large and small that grew and developed according to their environment. The kingdoms were divided into two parts based on the area they occupied. The kingdoms located on the coast were the Kingdoms of Tondong, Bulo-bulo and Lamatti. And the kingdoms that were in the highlands were the Turungen Kingdom, Manimpaoi, Terasa, Pao, Manipi, Suka and Bala Suka. ${ }^{11}$ After the

\footnotetext{
${ }^{10}$ Muh Anis, "Islamisasi Di Sinjai (Suatu Tinjauan Sejarah)," 2017.

${ }^{11}$ Abu Hamid, Jejak Kehadiran Sinjai Hingga Masuknya Islam (Padat Daya, 2002).
} 
Proclamation of Independence in 1945, namely October 20, 1959, Sinjai officially became a district based on Republic of Indonesia Law Number 29 of $1959 .{ }^{12}$ Sinjai is one of the districts as a producer of agriculture and fisheries. The prominent farms of Sinjai district are pepper and cacao. Pepper grows in almost all districts except in Pulau Sembilan sub-district. The planted area reaches 3,249 hectares with a total production of 2,380 per year. Meanwhile, cocoa or cocoa grows in almost all districts with a planted area of 4,178 hectares and annual yields of 2,129 tons. Sinjai exports these chocolates to Europe. ${ }^{13}$

Sinjai has 9 sub-districts, namely Sinjai north, south, east, west, central, borong, bulupoddo, tellu limpoe ', and nine islands. The district capital is in the northern Sinjai district. The total population of Sinjai Regency in 2014 was 236,497 people with a population growth rate of 3.3 percent from the 2010 Population Census, which amounted to 228,879 people. As many as $99 \%$ of the population of Sinjai Regency is Muslim. The entry of Islam in Sinjai.

The spread of Islam in the Sinjai area was inseparable from the role of Abdul Jawad Khatib Bungsu who was given the title Dato Tiro, he was one of the three Dato from the journey from Luwu to the south along the coast and finally arrived at Tiro (now Bulukumba). The regional symbol is an elliptical shield with a height and width ratio of 3: 2.There are historical buildings in Sinjai Regency, including the oldest mosque, the Almujahidin Mosque, which was founded in $1613 .{ }^{14}$ And the Nur mosque was founded in 1661.

Some of the scholars' figures who came from Sinjai were; Abdul Khatib Makmur Tunggal / Dato ri Bandang, Lagalago or Puang Belle, KH. Muhammad Thahir, KH. Marzuki Hasan, Abdullah Said and Hamzah Ya'qub.

\section{b. Local Culture of Sinjai Regency}

\section{1) Maddui Aju '/ The Tradition of Pulling Wood in Karampuang}

Madduik Aju is one of the many traditional traditions in Karampuang which is still preserved until now. Implementation is always awaited. Sometimes it makes you curious because you have to wait until the poles of traditional houses are rotten, usually 20 to 30 years. Besides the main event, namely Madduik Aju or pulling wood, this tradition always begins with various rituals. Like Masselung Ale 'or the process of exploring the forest which is still under customary authority to find suitable wood to be used as house poles. In order to easily pull it out, a custom device makes a hole in the end of the wood. In this hole, a large wooden branch is inserted which is connected to a length of 50 meters. The wooden branches that are drawn are called Hellareng, which is what people pull from inside the forest, usually from the sandalwood tree. Its length is approximately seven meters with a thickness of 50 centimeters. ${ }^{15}$

\footnotetext{
${ }^{12}$ Pemerintah Kabupaten Sinjai, "Sejarah Sinjai," n.d.

13 Anis, "Islamisasi Di Sinjai (Suatu Tinjauan Sejarah)."

${ }^{14}$ Saenal Abidin, Sinjai O Kilometer (Puzhacha Utama Mandiri, n.d.).

${ }^{15}$ Abidin.
} 


\section{2) Marrimpa Salo Culture '}

This Marrimpa Salo tradition existed before Islam entered Sinjai in 1607. However, after Islam became known in the area of the Tellu Limpoe Kingdom, several stages of the Marrimpa Salo Tradition which were deemed incompatible with Islamic Sharia disappeared by themselves, along with the increasing religious knowledge of the Sinjai people. Nevertheless, several stages of Marrimpa Salo which are full of local wisdom have been preserved until now. Like driving fish from upstream to river estuary using boats, using wooden beats and sounds to herd fish, playing drums and punching mortars to encourage those who chase fish, to entertainment programs such as Mallanca and Mappelo.

Until now, Marrimpa Salo has become the annual agenda of the Sinjai Regency Government. Through the Tourism and Culture Office of Sinjai Regency, the quality and quantity of activities at the Marrimpa Salo people's party is added to not diminishing the Marrimpa Salo characteristic that has existed for a long time. ${ }^{16}$

Based on what has been stated previously about the local Sinjai culture, then this description becomes the material for the preparation of Arabic lesson material for class VII Madrasah Tsanawiyah Darul Hikmah Sinjai through a process of selecting and simplifying information, so that the next stage is the selection and simplification of information about local Sinjai culture as already previously stated to compile class VII Arabic subject matter at Madrasah Tsanawiyah Darul Hikmah Sinjai.

c. The process of developing Arabic subject matter through the integration of local culture in Sinjai Regency into Arabic subject matter at Madrasah Tsanawiyah Darul Hikmah Sinjai

The development of subject matter is carried out through the following processes:

1) Analysis of Core Competencies and Basic Competencies The results of the analysis form the basis for the development of class VII Arabic learning material at Madrasah Tsanawiyah Darul Hikmah Sinjai by integrating local Sinjai culture into class VII Arabic learning materials at Mdrasah Tsanawiyah Darul Hikmah Sinjai.

2) Selection of Class VII Arabic Subjects at MTs Darul Hikmah Sinjai. This section is the stage of selecting and simplifying information about local Sinjai culture in the form of a simpler description or narrative. The information referred to is the result of literature studies and research field studies. The form of culture chosen to be the subject matter for class VII Arabic of Madrasah Tsanawiyah Darul Hikmah Sinjai is a form of culture in the form of activities or habits that exist in the Sinjai community and cultural heritage objects such as houses and certain buildings. The form of culture in the form of the chosen habits is as follows: Marrimpa salo 'and Maddui' aju '. Cultural forms in physical form or selected objects are as follows: Karampuang traditional house, Inscription to 'pekkong agreement, historic mosques and stones using gojeng.

\footnotetext{
${ }^{16}$ Abidin.
} 
3) Integration of Local Culture in Class VII Arabic Learning Materials of MTs Darul Hikmah Sinjai. The integration of local culture in Arabic subject matter for grade VII at Madrasah Tsanawiyah Darul Hikmah Sinjai means to unite elements of local Sinjai culture into class VII Arabic subject matter at Madrasah Tsanawiyah Darul Hikmah Sinjai. So that the integration of local culture is not just the translation of narratives or materials about local Sinjai culture into Arabic, but there are elements of local Sinjai culture that are integrated into the subject matter of class VII Arabic Madrasah Tsanawiyah Darul Hikmah Sinjai which makes this integration a form of cultural integration. local into the subject matter.

4) Compilation of Class VII Arabic Teaching Materials at MTs Darul Hikmah Sinjai. The output of this study is the existence of new teaching materials, namely Arabic textbooks for grade VII Madrasah Tsanawiyah Darul Hikmah Sinjai. The book in question is the result of the researcher's development by integrating local Sinjai culture into the subject matter of Arabic for grade VII Madrasah Tsanawiyah Darul Hikmah Sinjai.

5) Product trials. The trial process consists of two parts, namely internal testing conducted by subject matter experts, Arabic grammar experts. External testing is also called product testing conducted by Arabic subject teachers and the head of Madrasah and tested on seventh grade students of Madrasah Tsanawiyah Darul. Sinjai Wisdom.

6) Final product designation. The final product is a product that has been proportionally validated by subject matter experts and grammar experts and has been tested on teachers and students of Madrasah Tsanawiyah Darul Hikmah Sinjai.

d. Feasibility Level of Products Result of Learning Material Development Through the Integration of Local Culture in Sinjai Regency into Arabic Language Learning Materials at Madrasah Tsanawiyah Darul Hikmah Sinjai

1) Internal Test To determine the feasibility level of the product, a testing process is carried out. The testing process is divided into two parts, namely, internal and external tests. The internal test includes testing by experts which is divided into two, namely material experts and Arabic grammar experts covering four aspects, namely, material aspects, presentation, content systematics, and grammar aspects and external testing includes testing by Arabic teachers, students and principals of Madrasah Tsanawiyah Darul Hikmah Sinjai. To find out the results of the internal test, a descriptive analysis was carried out on each internal aspect and the following is a descriptive analysis of the internal aspects:

a) Material Aspects

Table 1 Descriptive Statistics of Material Aspects

Descriptive Statistics

\begin{tabular}{lrrrrr}
\hline & N & Minimum & Maximum & Mean & Std. Deviation \\
\hline $\begin{array}{l}\text { Material Expert Validation } \\
\text { Material Aspects }\end{array}$ & 2 & 31 & 32 & 31,50 &, 707
\end{tabular}


Based on the results of descriptive analysis in table 1, it is known that the minimum value is 31 , the maximum value is 32 , the mean is 31.50 , the number of respondents is 2 and the standard deviation is 0.707 .

b) Presentation Aspects

Table 2 Descriptive Statistics for Presentation Aspects

Descriptive Statistics

\begin{tabular}{|c|c|c|c|c|c|}
\hline & $\mathrm{N}$ & Minimum & Maximum & Mean & Std. Deviation \\
\hline $\begin{array}{l}\text { Material Expert Validation } \\
\text { for Presentation Aspects }\end{array}$ & & 19 & 23 & 21,00 & 2,828 \\
\hline Valid N (listwise) & & 2 & & & \\
\hline
\end{tabular}

Based on the results of descriptive analysis in table 2, it is known that the minimum value is 19 , the maximum value is 23 , the mean is 21.00 , the number of respondents is 2 and the standard deviation is 2.828 .

c) Content Systematic Aspects

Table 3 Descriptive Statistics of Content Systematics Aspects

Descriptive Statistics

\begin{tabular}{lcrrrr|}
\hline & N & Minimum & Maximum & Mean & Std. Deviation \\
\hline $\begin{array}{l}\text { Material Expert Validation } \\
\text { on Systematic Aspects of }\end{array}$ & 2 & 22 & 26 & 24,00 & 2,828 \\
$\begin{array}{l}\text { Content } \\
\text { Valid N (listwise) }\end{array}$ & 2 & & & & \\
\hline
\end{tabular}

Based on the results of descriptive analysis in table 3, it is known that the minimum value is 22 , the maximum value is 26 , the mean is 24.00 , the number of respondents is 2 and the standard deviation is 2.828 .

d) Aspects of Arabic Grammar

Table 4 Descriptive Statistics of Arabic Grammar Aspects

Descriptive Statistics

\begin{tabular}{|c|c|c|c|c|c|}
\hline & $\mathrm{N}$ & Minimum & Maximum & Mean & Std. Deviation \\
\hline $\begin{array}{l}\text { Grammar Expert } \\
\text { Validation }\end{array}$ & & 9 & 11 & 10,00 & 1,414 \\
\hline Valid N (listwise) & & & & & \\
\hline
\end{tabular}

Based on the results of the descriptive analysis in table 4 above, it is known that the minimum value is 9 , the maximum value is 12 , the mean is 10.60 , the number of responses is 5 and the standard deviation is 1.140 . 
After tabulating each aspect tested, the percentage is obtained, then the internal test result value recapitulation will be carried out. This is done to see the highest and lowest percentages, so that the aspect with the lowest percentage will be seen and the aspect with the highest percentage. The following is a recapitulation of the internal test results:

Table 5 Recapitulation of Internal Test Result Values

\begin{tabular}{lccc}
\hline Aspects Tested & Maximum Value & Total Value & Percentage \\
\hline Subject Matter & 80 & 63 & $78,75 \%$ \\
Presentation & 56 & 42 & $75 \%$ \\
$\begin{array}{l}\text { Content } \\
\text { Systematics }\end{array}$ & 56 & 48 & $85,71 \%$ \\
Grammar & 32 & 20 & $62,5 \%$ \\
\multicolumn{1}{c}{ Total : } & 224 & 173 & $301,96 \%$ \\
\multicolumn{1}{c}{ Mean : } & 56 & 43,25 & $75.49 \%$ \\
\hline
\end{tabular}

To determine the lowest and highest percentages and the average obtained, a descriptive analysis was carried out using SPSS. And here are the results:

Table 6 Descriptive Statistics of Internal Test

Descriptive Statistics

\begin{tabular}{|c|c|c|c|c|c|}
\hline & $\mathrm{N}$ & Minimum & Maximum & Mean & Std. Deviation \\
\hline Uji Internal & & 20 & 63 & 43,25 & 17,840 \\
\hline $\begin{array}{l}\text { Valid N } \\
\text { (listwise) }\end{array}$ & & & & & \\
\hline
\end{tabular}

Descriptive analysis in table 6 is a descriptive analysis of the total value for each existing aspect. Based on the table, it is known that the minimum score is 20 which is the grammar aspect and the maximum score is 63 which is the material aspect. If the total value of each aspect is totaled then the percentage is determined, the results are as follows:

Table 7 Percentage of Internal Test

\begin{tabular}{lcc}
\hline Aspects Tested & $\begin{array}{c}\text { Total } \\
\text { Value }\end{array}$ & Percentage \\
\hline Subject Matter & 63 & $36,41 \%$ \\
\hline
\end{tabular}




\begin{tabular}{|c|c|c|}
\hline Presentation & 42 & $24,27 \%$ \\
\hline Content Systematics & 48 & $27,76 \%$ \\
\hline Grammar & 20 & $11,56 \%$ \\
\hline Total : & 173 & $100 \%$ \\
\hline
\end{tabular}

Based on table 7, it is known that the total value is 173. And the highest percentage is $36.41 \%$, namely the material aspect and the lowest percentage is $11.56 \%$, namely the grammar aspect. The percentage obtained is different from the test results for each aspect, this is because the number of respondents and the number of items on the instrument are different. Based on the percentage results, it can be seen that the weakest and strongest aspects of the product produced. 2) External Test Before doing statistical analysis using paired test or $t$ test, then as a prerequisite for doing the analysis is the data normality test. The following are the results of the data normality test:

Table 8 The Kolmogorov-Smirnov and Shapiro-Wilk Data Normality Test

Tests of Normality

\begin{tabular}{llrrrrrrr}
\hline & Kelas & \multicolumn{3}{c}{$\begin{array}{c}\text { Kolmogorov- } \\
\text { Smirnova }\end{array}$} & \multicolumn{4}{c}{ Shapiro-Wilk } \\
& & Statistic & Df & Sig. & Statistic & Df & Sig. \\
\hline Students' Language & Pre-Test & .156 & 22 & .177 & .933 & 22 & .140 \\
Ability & Pos-Test & .193 & 22 & .032 & .905 & 22 & .037 \\
\hline
\end{tabular}

a. Lilliefors Significance Correction

Based on the results of the data normality test in Table 8 , it is known that the data is not normally distributed because the sig value in the post-test for the Kolmogorov-Smirnov and Shapiro-Wilk types is smaller than $0.05(.032<0.05)$ and $(.037<0.05)$. Based on this, the subsequent analysis did not use parametric statistical analysis but used nonparametric statistical analysis of the Wilcoxon type. The following are the results of the nonparametric statistical analysis of the Wilcoxon type:

Table 9 Nonparametric Statistical Analysis for the Wilcoxon Type

\begin{tabular}{llrrr}
\hline \multicolumn{4}{c}{ Ranks } \\
& \multicolumn{1}{c}{ N } & Mean Rank & Sum of Ranks \\
\hline \multirow{4}{*}{ Pos Test - Pre Test } & Negative Ranks & $3^{\mathrm{a}}$ & 8.17 & 24.50 \\
& Positive Ranks & $17^{\mathrm{b}}$ & 10.91 & 185.50 \\
& Ties & $2^{\mathrm{c}}$ & & \\
& Total & 22 & & \\
\hline
\end{tabular}
a. Pos Test $<$ Pre Test
b. Pos Test $>$ Pre Test
c. Pos Test $=$ Pre Test 
Based on the results of data analysis in Table 9, it is known that there are 3 negative ranks, which means that there are 3 post-test values that are smaller than the pre-test. In the positive ranks section there are 17 data, which means that there are 17 data whose post-test values are greater than the pre-test values. In the ties section there are 2 data, which means that there are 2 data which the post-test value is the same as the pre-test value.

To find out, the level of product eligibility for use on students, the significant value of the analysis results must be less than 0.05 and the results of the Wilcoxon-type nonparametric statistical analysis are as follows:

Table 10 Wilcoxon Type Nonparametric Statistical Tests

\begin{tabular}{lr}
\multicolumn{2}{c}{ Test Statistics $^{\mathbf{a}}$} \\
\hline $\begin{array}{c}\text { Pos Test - Pre } \\
\text { Test }\end{array}$ \\
\hline $\mathrm{Z}$ & $-3.012^{\mathrm{b}}$ \\
$\begin{array}{l}\text { Asymp. Sig. (2- } \\
\text { tailed) }\end{array}$ & .003 \\
\hline
\end{tabular}

a. Wilcoxon Signed Ranks Test

b. Based on negative ranks.

Based on the results of the analysis in Table 10, it is known that the asymp.sig value or the significance value is .003 . this means that $.003<0.05$. Based on this, the product in the form of an Arabic book that is integrated with the local Sinjai culture is suitable for use by grade VII students at Madrasah Tsanawiyah Darul Hikmah Sinja.

\section{e. Discussion}

The integration of local culture into Arabic subject matter at Madrasah Tsanawiyah Darul Hikmah Sinjai is carried out using tree theory. The use of tree theory is more relevant to the conditions of the Sinjai community, in this case the students at Madrasah Tsanawiyah Darul Hikmah Sinjai, especially grade VII students. Philosophically, the implementation of Tree Theory in this study is to make local culture a fundamental thing in student learning in Arabic subjects in class VII Madrasah Tsanawiyah Darul Hikmah Sinjai, namely as subject matter.

Practically, tree theory is implemented by incorporating local culture in every part of the class VII Arabic subject matter at Madrasah Tsanawiyah Darul Hikmah Sinjai such as reading material, conversations, example sentences, expressions and practice questions.

The tree theory is the theoretical basis in the process of integrating local sinjai culture into the seventh grade Arabic language learning material at the Tsanawiyah madrasa. This can be seen in:

1) The existence of cultural elements which are the basis of the subject matter in the products made.

2) The reading text, which is the main element in the subject matter, entirely discusses elements of local culture, both from the title of the reading to the content and substance of the reading. 
3) Vocabulary, example sentences, expressions and practice questions are a part that is coherent with the substance of the reading in which there are elements of local Sinjai culture.

4) Layout or product display physically presents regional elements.

The pictorial instruments in the material are one of the elements of local Sinjai culture. For example, a miniature of the Karampuang traditional house and the Marrimpa Salo culture.

\section{CONCLUSION}

a. The process of developing Arabic learning material for grade VII Madrasah Tsanawiyah Darul Hikmah Sinjai which is integrated with local Sinjai culture has six stages as follows: 1) Conducting field studies and literature studies on local Sinjai culture and several things related to Sinjai. 2) Determining and compiling material from literature and field studies 3) Integration of local culture into class VII Madrasah Tsanawiyah Darul Hikmah Sinjai subject matter.

4) Systematize the material that has been translated according to the theory used.

5) Material testing includes internal testing and external testing. The internal test was carried out by subject matter experts, Arabic grammar experts. For external testing, it is also called product testing conducted by Arabic subject teachers and Madrasah principals and tested on seventh grade students of Madrasah Tsanawiyah Darul Hikmah Sinjai. 6) Final product designation.

b. The product produced in this research and development is an Arabic textbook for class VII Madrasah Tsanawiyah which is integrated with local Sinjai culture with the percentage of internal validation results covering five aspects the average percentage reaches $64.02 \%$ and the results of field trials using nonparametric statistical analysis Wilcoxon type. is .003 which means less than $0.05(003<0.05)$ this means that this product is suitable for use.

\section{BIBLIOGRAPHY}

Abidin, Saenal. Sinjai 0 Kilometer. Puzhacha Utama Mandiri, n.d.

Anis, Muh. "Islamisasi Di Sinjai (Suatu Tinjauan Sejarah)," 2017.

Emzir, Metodologi. Metodologi Penelitian Pendidikan: Kuantitatif Dan Kualitatif. Jakarta: Raja Grafindo Persada, 2015.

Hamid, Abu. Jejak Kehadiran Sinjai Hingga Masuknya Islam. Padat Daya, 2002.

Mulabbiyah, Mulabbiyah. "Implementasi Kurikulum 2013 Pada Mata Pelajaran Pendidikan Agama Islam Berdasarkan KMA Nomor 165 Tahun 2014 Di Madrasah.” Jurnal Tatsqif 16, no. 2 (2018): 108-25.

Munir, M Ag. Perencanaan Sistem Pengajaran Bahasa Arab; Teori Dan Praktik. Kencana Prenada Media Group, 2017.

Sinjai, Pemerintah Kabupaten. "Sejarah Sinjai," n.d.

Sugiyono, Prof. Metode Penelitian Kuantitatif, Kualitatif Dan R\&D. Alpabeta, Bandung, 2017. 


\section{Integration of Local Culture in Arabic Lesson Materials}

in Madrasah Tsanawiyah Darul Hikmah Sinjai

Sunarto, Hartono\&, and Agung Hartono. Perkembangan Peserta Didik. Jakarta: Rineka Cipta, 2018.

Syaodih Sukmadinata, Nana. Metode Penelitian Pendidikan. Bandung: Remaja Rosda Karya, 2013. 